\title{
8-mm portal incarcerated hernia after robotic colectomy: case report
}

Hérnia portal encarcerada de $8 \mathrm{~mm}$ depois de colectomia robótica: relato de caso

Hérnia portal encarcelada de $8 \mathrm{~mm}$ después de la colectomía robótica: reporte de caso

João Victor Tavares Mendonça Garretto ${ }^{1 *}$, Yara Tavares Mendonça Garretto², Thales Hott Fernandes Morais ${ }^{2}$, Sofia Gonzaga Garcia², Luisa Leal Barbosa Correia de Andrade ${ }^{2}$, Maria Paula de Mello Nogueira ${ }^{2}$, Marcela Lima Castro Curi², Maria Raquel Junqueira ${ }^{2}$, Louise D'Arrigo Luchese ${ }^{2}$, Luiza Zaidan de Souza Prado ${ }^{3}$.

\begin{abstract}
Objective: The objective of this work is to report a hernia derived from the access portal used in robotic surgery. Details of the case: A 72-year-old woman, diagnosed with splenic angle adenocarcinoma of the colon, underwent robotic left colectomy and lymphadenectomy. On the 12th postoperative day, she developed vomiting and interrupted the elimination of feces and flatus. Computed tomography revealed hernia on the left flank with an $8 \mathrm{~mm}$ orifice with intestinal contents. Incisional herniorrhaphy was performed to correct the defect. $\mathrm{PSH}$ are associated with patient risk factors. They are also related to the diameter of the trocar and its place of passage. For its prevention, it is important to assess the need to close the aponeurosis according to each case. Final considerations: The disturbances created by the passage of $12 \mathrm{~mm}$ and $10 \mathrm{~mm}$ trocars must be closed. Those created by $5 \mathrm{~mm}$ trocars do not need to be closed, and those of $8 \mathrm{~mm}$ may or may not be closed, depending on the risk factors involved.
\end{abstract}

Key words: Robotic surgery, Incisional hernia, Colectomy, Herniorrhaphy.

\section{RESUMO}

Objetivo: O objetivo deste trabalho é relatar uma hérnia derivada do portal de acesso usado em uma cirurgia robótica. Detalhamento do caso: Uma mulher, de 72 anos, diagnosticada com adenocarcinoma de ângulo esplênico do cólon, foi submetida a colectomia esquerda robótica e linfadenectomia. No $12^{\circ}$ dia de pósoperatório, desenvolveu vômitos e interrompeu a eliminação de fezes e flatos. A tomografia computadorizada revelou hérnia em flanco esquerdo com orifício de $8 \mathrm{~mm}$ com conteúdo intestinal. Foi realizada herniorrafia incisional para correção do defeito. As HSP estão associadas a fatores de risco do paciente. Relacionam-se, também, ao diâmetro do trocartee seu local de passagem. Para sua prevenção é importante avaliar a necessidade de fechamento da aponeurose de acordo com cada caso. Considerações finais: Os distúrbios criados pela passagem de trocartes de $12 \mathrm{~mm}$ e $10 \mathrm{~mm}$ devem ser fechados. Aqueles criados por trocartes de $5 \mathrm{~mm}$ não precisam ser fechados, e os de $8 \mathrm{~mm}$ podem ou não ser fechados, dependendo dos fatores de risco envolvidos.

Palavras-chave: Cirurgia robótica, Hérnia incisional, Colectomia, Herniorrafia.

\section{RESUMEN}

Objetivo: El objetivo de este trabajo es reportar una hernia derivada del portal de acceso utilizado en cirugía robótica. Detalles del caso: Una mujer de 72 años, diagnosticada de adenocarcinoma de colon del ángulo esplénico, fue sometida a colectomía izquierda robótica y linfadenectomía. Al duodécimo día postoperatorio

\footnotetext{
1 Biocor Hospital, Belo Horizonte - MG. *E-mail: jvgarreto@gmail.com

2 Medical Sciences Faculty of Minas Gerais, Belo Horizonte - MG.

${ }^{3}$ Federal University of Ouro Preto, Ouro Preto - MG.
} 
desarrolló vómitos e interrumpió la eliminación de heces y flatos. La tomografía computarizada reveló hernia en flanco izquierdo con orificio de $8 \mathrm{~mm}$ con contenido intestinal. Se realizó herniorrafia incisional para corregir el defecto. Las HSP están asociadas con factores de riesgo del paciente. También están relacionados con el diámetro del trócar y su lugar de paso. Para su prevención, es importante valorar la necesidad de cerrar la aponeurosis según cada caso. Consideraciones finales: Deben cerrarse las perturbaciones creadas por el paso de trócares de $12 \mathrm{~mm}$ y $10 \mathrm{~mm}$. Los creados por trócares de $5 \mathrm{~mm}$ no necesitan ser cerrados, y los de $8 \mathrm{~mm}$ pueden estar cerrados o no, dependiendo de los factores de riesgo involucrados.

Palabras clave: Cirugía robótica, Hernia incisional, Colectomía, Herniorrafia.

\section{INTRODUCTION}

Portal site hernias (PSH) are entities that occur in patients undergoing laparoscopic or robotic surgery, in which there is a herniation of abdominal content by the created disturbance due to passage of the trocar. These hernias are associated with patient-related risk factors and inherent risk factors of the surgical procedure itself (CHO W, et al., 2019; DIEZ-BARROSO R, et al., 2018).

The incidence of hernias is associated with the portal diameter. In the $12 \mathrm{~mm}$ portals it is approximately $0.8 \%$ and in the $8 \mathrm{~mm}$ portals it is $0.68 \%$. In some studies, there are no reports of hernias in the $5 \mathrm{~mm}$ trocars. The most common places for the onset of PSH are the midline and the regions near muscular insertion, where the ability of muscle fibers to overlap and close the defect is lower (DIEZ-BARROSO R, et al., 2018; CORCIONE F, et al., 2004; KOCHER N, et al., 2017).

Although rare, when PSH occurs, it can cause serious complications, and in some cases, surgical approach is indicated. Thus, PSH are important pathologies that should be avoided, and closing the aponeurosis where the trocar was passed is the best way to do so (KOCHER N, et al., 2017; OWENS M, et al., 2011; SINGAL R, et al., 2016).

Currently, it has been discussed under what circumstances and occasions the aponeurosis suture should be performed to prevent PSH. Hence, all orifice created by trocars of $10 \mathrm{~mm}$ or more should be closed, and it is not necessary to close those created by trocars of $5 \mathrm{~mm}$. $8 \mathrm{~mm}$ trocars may or may not be closed, depending on where it was passed and the risk factors of the patient and the procedure. There are several opinions on whether facial closure should be done when $8 \mathrm{~mm}$ trocars are used in robotic surgeries. Some authors argue that facial closure should be done routinely, while others claim that it is not necessarily due to a perceived low risk of PSH (DIEZ-BARROSO R, et al., 2018; LIM S, et al., 2013; TSU J, et al., 2013; KILIC G, et al., 2014; VENCLAUSKAS L, et al., 2017).

The objective of this work is to report hernias derived from the portals used in robotic surgery, which are possible complications of this kind of procedure. These events are little covered in the literature, and are a rare complication, but their knowledge is important for surgical success, avoiding future discomfort in the postoperative period of patients undergoing this technique.

\section{CASE DETAILS}

A 72-year-old female patient diagnosed with splenic-angle colon adenocarcinoma underwent robotic left hemicolectomy and retroperitoneal lymphadenectomy. After histological analysis, poorly differentiated invasive colonic adenocarcinoma was found, which infiltrated subserosal layer without angiolymphatic involvement and absence of lymph node metastasis, defining the disease as stage II, which does not indicate adjuvant therapy.

The patient evolved on the 12th postoperative day with episodes of vomiting and stopped eliminating feces and flatus. On examination, the patient presented dry and well-functioning operative wounds, a flaccid, painless abdomen, present airborne noises, with no signs of peritoneal irritation. A CT scan was performed, which showed a herniation in the left iliac fossa, in a hole measuring $08 \mathrm{~mm}$, in addition to upstream distension and collapse of distal ileal segments to the herniated point (Figure 1). 
Figure 1 - Computed tomography (TC) with the hernia in the left iliac fossa.

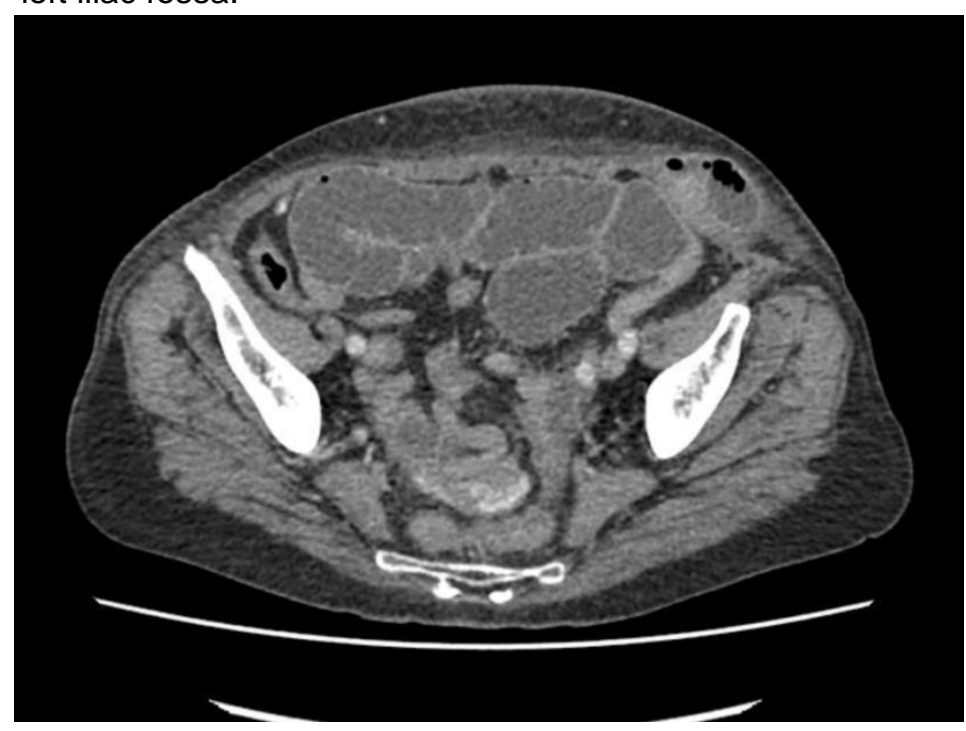

Source: Garretto JVTM, et al., 2021.

Incisional hernia was diagnosed in the left flank originating from a robotic portal scar of $8 \mathrm{~mm}$. Then, the patient underwent incisional herniorrhaphy to correct the defect and then proceeded with a physiological postoperative period (Figure 2).

Figure 2 - Content of incisional hernia during the correction (Own collection).

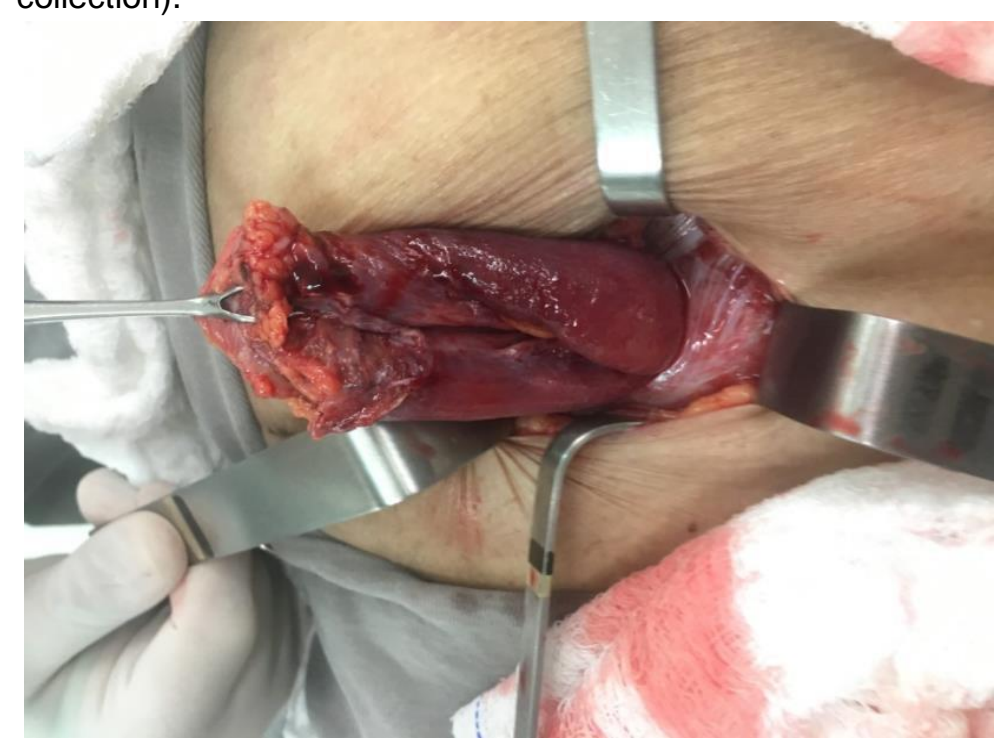

Source: Garretto JVTM, et al., 2021.

\section{DISCUSSION}

Robotic surgery is a gateway that has revolutionized minimally invasive surgery. From the surgeon's point of view, there was increased comfort to perform the procedures, greater mobility of surgical instruments, and better three-dimensional image quality. In addition, patient benefits are identified, such as reduced postoperative pain and time of hospitalization, lower rates of cardiac, pulmonary, and surgical wound complications. However, this technology is not exempt of complications, and one of them is portal site hernia (PSH), once it relies on larger working ports in cross sectional diameter, such as $8 \mathrm{~mm}$ ports. As the use of robotic platform is emerging, the establishment of how port sizes and locations relate with PSH in robotic 
surgeries lacks better definition. Besides that, it still remains uncertain whether facial closure when 8mm ports are used - which are unique in robots -is necessary or not (CHO W, et al., 2019; DIEZ-BARROSO R, et al., 2018; CORCIONE F, et al., 2004).

PSH is defined as an incisional hernia following surgery involving the passage of trocars, whether robotic or laparoscopic. Despite being a rare complication, it can lead to serious events such as hernia entrapment or strangulation, or bowel evisceration, leading patients to undergo urgent surgery ( $\mathrm{CHO}$ W, et al., 2019; KOCHER N, et al., 2017).

The incidence of PSH in robotic surgery is low, ranging from $0 \%$ to $5.2 \%$, and most are related to the use of trocars over $10 \mathrm{~mm}$ and at the umbilical scar site (CORCIONE F, et al., 2004). Trocars that are laterally punctured have lower rates of hernia development, because the coaptation of the abdominal muscles induces natural closure of the orifice. However, the true incidence of these hernias is underestimated, since most are asymptomatic and are only observed when imaging is performed, which makes the diagnosis difficult (DIEZBARROSO R, et al., 2018).

Risk factors for PSH development can be divided in factors associated with the patient and the surgical procedure itself (Table 1). Patient-related factors are obesity, increased abdominal pressure (constipation, cough), malnutrition, diabetes mellitus, chemotherapy, smoking and infection (DIEZ-BARROSO R, et al., 2018; CORCIONE F, et al., 2004). The surgery-related factors consist in the size of the trocar, the use of trocars with blade, the surgery duration, place of trocar insertion, excessive or inappropriate manipulation of forceps during surgery, manner of insertion and removal of trocars, and failure or non-closure of trocar insertion, depending on the diameter of these instruments (CHO W, et al., 2019; KOCHER N, et al., 2017; OWENS M, et al., 2011).

Regarding the clinical manifestations of PHS, the onset of symptoms usually occurs within a few days after surgery, but they can occur up to months of the intervention. The median interval in early-onset cases is 5 days, and in the late-onset cases the interval is 5.5 months. The clinical presentation can vary from asymptomatic hernias, manifested only by a bulge, to small-bowel obstruction, due to incarceration or strangulation of the hernia (TONAUCHI, H., et al., 2004).

Table 1 - Risk Factors.

\begin{tabular}{cc}
\hline Related to patient & Related to the surgery \\
\hline Obesity & Size of the trocar \\
Increased abdominal pressure & Use of trocars with blade \\
Malnutrition & Excessive manipulation \\
Diabetes Mellitus & Place of the trocar insertion \\
Chemotherapy & Failure of the trocar insertion \\
Smoking & Non-closure of trocar insertion \\
Infection &
\end{tabular}

Source: Garretto JVTM, et al., 2021.

The main occurrence of PSH is related to trocars passed in the midline of the abdomen and to trocars with a diameter greater than $10 \mathrm{~mm}$ are used. Given the widespread use of laparoscopic surgery, most studies on portal hernias address laparoscopic procedures. Studies show that $96 \%$ of hernias at trocar sites originate in places where there has been a trocar passage of at least $10 \mathrm{~mm}$ in diameter, and $82 \%$ are located in the umbilical region (DIEZ-BARROSO R, et al., 2018; OWENS M, et al., 2011; TSU J, et al., 2013).

To reduce the incidence of hernias in trocars larger than $10 \mathrm{~mm}$ in the midline, and to control most of the risk factors, closing the aponeurosis is necessary and well established in literature. Furthermore, $8 \mathrm{~mm}$ trocars or smaller, that are placed laterally, do not have closed aponeurosis routinely performed due to the lower incidence of hernias. However, some hernias are still reported in these places (DIEZ-BARROSO R, et al., 2018; KILIC G, et al., 2014).

A retrospective study analyzed 178 patients undergoing digestive tract robotic surgeries using the da Vinci Si platform (Intuitive Surgica), divided into 68 rectal surgeries, 32 colon surgeries, 25 hepatobiliary surgeries, 21 inguinal hernia surgeries and 28 other surgeries. In this study, a total of 725 portals were used, including 
433 portals of $8 \mathrm{~mm}, 72$ of $12 \mathrm{~mm}$ for assistance and 178 of $12 \mathrm{~mm}$ for the camera. All portals larger than 10 $\mathrm{mm}$ were closed with Vicryl 0 , while none of the $8 \mathrm{~mm}$ portals or smaller were closed. After analysis of the results, 2 hernias in $12 \mathrm{~mm}$ portals, 3 hernias in $8 \mathrm{~mm}$ portals and no hernias in $5 \mathrm{~mm}$ portal were reported. Hernias in the $12 \mathrm{~mm}$ trocars occurred at the umbilical scar site and the $8 \mathrm{~mm}$ portals were passed outside the midline (DIEZ-BARROSO R, et al., 2018; KILIC G, et al., 2014).

Based on the same study, it is clear that PSH are rare entities, considering that the incidence among the total number of surgeries using trocars corresponds to $0.68 \%$. The hernias that originated at the place of passage of the $12 \mathrm{~mm}$ trocars corresponded to $0.8 \%$ of these, and the hernias from the $8 \mathrm{~mm}$ portals corresponded to only $0.69 \%$ of all of the trocars used (DIEZ-BARROSO R, et al., 2018).

Regarding laparoscopic surgery, guidelines establish thatthe closure of the aponeurosis in 10and $5 \mathrm{~mm}$ portals can be performed or not. With the advent of robotic surgery, there was the emergence of a new portal modality, of $8 \mathrm{~mm}$. In these portals, the incidence of incisional hernia is low. However, when strangulation of loops occurs, it is associated with high morbidity due to ischemia of the affected intestinal follow-up, requiring, in some cases, surgical re-approach, which is undesirable (DIEZ-BARROSO R, et al., 2018; OWENS M, et al., 2011; SINGAL R, et al., 2016; PARK M, et al., 2012).

The muscles that make up the abdominal wall are the external oblique muscle, internal oblique muscle, and transverse muscle, and they all present different muscle fibers arrangements. Despite the fact that they are incised with the passage of the trocars, these fibers usually slip and occlude the created disturbance. However, if the muscle is incised near its insertion site, the ability of the muscle to slip and tamponade decreases, which may make some regions more susceptible to HSP formation, such as the region near the anterior superior iliac spine (DIEZ-BARROSO R, et al., 2018; PARK M, et al., 2012; VENCLAUSKAS L, et al., 2017).

Moreover, some authors consider that $8 \mathrm{~mm}$ trocars should be closed when punctured at or near the midline of the abdominal wall muscles insertion. Another indication for $8 \mathrm{~mm}$ portal fascia suture is when the patient has known risk factors for hernia formation, for example: obesity, situations of increased abdominal pressure, surgical site infection, among others. In obese patients it is difficult to locate the fascial layer where the " remote center " of the robotic arm will be fixed. Furthermore, in patients with a high body mass index (BMI), the peritoneal defect will be bigger. (CHO W, et al., 2019; DIEZ-BARROSO R, et al., 2018; TSU J, et al., 2013).

However, in another retrospective study in which 188 patients underwent robotic colorectal surgery, the fasciae of all trocars larger than $10 \mathrm{~mm}$ with Vicryl 0 suture were closed. Portals of $8 \mathrm{~mm}$ or less were passed laterally to the midline and did not have their fascia closed. In this study, no herniations were reported in the $13,12,10,8$ or $5 \mathrm{~mm}$ portals, either by physical examination or by radiological methods. The authors state that the closure of the trocar fascia above $10 \mathrm{~mm}$ is well established, but for trocars of $8 \mathrm{~mm}$ or less, due to the non-appearance of HSP in this analysis, it is unnecessary to establish routine closure, especially if the trocars were passed outside the midline (HARR J, et al., 2015).

Although PSH in $8 \mathrm{~mm}$ portals used in robotic surgeries are rare, they represent a possible complication that can lead to severe outcomes to the patient, so analyzing the risk factors is important for preventing them. The literature is well established regarding aponeurotic closure in surgeries with 10 and $12 \mathrm{~mm}$ trocars, and regarding the lack of suture in $5 \mathrm{~mm}$ portals. Regarding $8 \mathrm{~mm}$ trocars, the closure of the aponeurosis should be performed according to the presented risk factors, both patient and surgery related, as discussed in this article. In the absence of these factors, closing is not necessary. Further long-term observation of patients that underwent robotic surgeries with $8 \mathrm{~mm}$ ports is also needed to fully establish the incidence of PSH and the impact of ports facial closure in preventing further complication.

\section{REFERENCES}

1. BOWREY DJ, et al. Risk factors and the prevalence of exchanging site herniation after laparoscopic fundoplication. Surgical Endoscopy. 2001; 15(7): 663-6. 
2. BUCKLEY FP, et al. Influencing factors for port-site hernias after single-incision laparoscopy. Hernia. 2016; 20(5): 729-33.

3. $\mathrm{CHO}$ W, et al. Is the 8-mm robotic port safe? A case of swapping site hernia after robotic cholecystectomy using the da Vinci Xi system. Wideochir Inne Tech Maloinwazyjne, 2019; 14(1): 137-140.

4. CHRISTIE M, et al. Occult Radiographically Evident Port-Site Hernia After Robot-Assisted Urologic Surgery: Incidence and Risk Factors. Journal of Endourology, 2016; 30(1): 92-6.

5. CORCIONE F, et al. Advantages and limits of robot-assisted laparoscopic surgery. Surgical Endoscopy, 2005; 19(1): 117-9.

6. DIEZ-BARROSO R, et al. Robotic port-site hernias after general surgical procedures. Journal of Surgical Research, 2018; 230: 7-12.

7. HARR J, et al. Incisional and port-site hernias following robotic colorectal surgery. Surgical Endoscopy, 2016; 30(8): 3505-10.

8. KILIC G, et al. Exchange site hernia on an 8-mm port following robotic-assisted hysterectomy. Journal of the Chinese Medical Association, 2014; 77(2): 112-4.

9. KOCHER N, et al. Incarcerated Right Side Swap-Site Hernias a Rare Complication of Robot-Assisted Laparoscopic Prostatectomy J. Journal of Endourology Case Reports, 2017; 3(1): 155-157.

10. LIM S, et al. A rare case of incisional hernia interparietal from $8 \mathrm{~mm}$ exchange site after robot-assisted laparoscopic prostatectomy. Hernia. 2014; 18(6): 911-3.

11. OWENS M, et al. A systematic review of laparoscopic site hernias in gastrointestinal surgery. The Surgeon Journal of the Royal Colleges of Surgeons of Edinburg and Ireland, 201; 9(4): 218-24.

12. PARK M, et al. Change Site Hernia After the Use of 12-mm BladelessSwap in Robotic Colorectal Surgery. Surg Laparosc Endosc Percutan Tech, 2012; 22(1): e34-6.

13. SINGAL R, et al. No Need for Fascia Closure to Reduce Exchange Site Hernia Rate in Laparoscopic Surgery: A Prospective Study of 200 Non-Obese Patients. Gastroenterol Res, 2016; 9(4-5): 70-73.

14. TONAUCHI H, et al. Trocar site hérnia. Archieves of Surgery, 2004; 139(11): 1248-56.

15. TSU J, et al. Change-site hernia at the $8-\mathrm{mm}$ robotic port after robot-assisted laparoscopic prostatectomy: a case report and review of the literature. J Robotic Surg, 2014; 8(1): 89-91.

16. VENCLAUSKAS L, et al. Long-term follow-up results of umbilical hernia repair. Videosurgery Miniinv, 2017; 12: 3506. 